\title{
Tin(II) Selective PVC Membrane Electrode Based on Salicylaldehyde Thiosemicarbazone as an Ionophore
}

\author{
Sulekh Chandra, ${ }^{1}$ Kusum Sharma, ${ }^{2}$ and Adarsh Kumar ${ }^{1,2}$ \\ ${ }^{1}$ Department of Chemistry, Zakir Husain College University of Delhi, J. L. Nehru Marg, New Delhi 110002, India \\ ${ }^{2}$ Department of Applied Chemistry, MAIT, GGSIPU, Sector 22, Rohini, New Delhi 110075, India
}

Correspondence should be addressed to Sulekh Chandra; schandra_00@yahoo.com

Received 27 December 2011; Revised 12 June 2012; Accepted 16 June 2012

Academic Editor: Haridas Pal

Copyright (C) 2013 Sulekh Chandra et al. This is an open access article distributed under the Creative Commons Attribution License, which permits unrestricted use, distribution, and reproduction in any medium, provided the original work is properly cited.

A polymeric membrane-based tin selective electrode was developed by using salicylaldehyde thiosemicarbazone (STSC). The best performance was recorded with a membrane composition of PVC:TBP : ionophore: NaTPB as 28:59:8:5 (w/w\%). The Nernstian slope calculated from the calibration curve for $\mathrm{Sn}^{2+}$ sensor was $28.8 \pm 0.4 \mathrm{mV} /$ decade. The detection limit of the sensor was $2.10 \times$ $10^{-8} \mathrm{M}$, in the linear concentration range of $1.0 \times 10^{-2}-1.1 \times 10^{-7} \mathrm{M}$. It was relatively fast response time $(<8 \mathrm{~s}$ for concentration $\geq 1.0 \times 10^{-4}$ and $<12 \mathrm{~s}$ for concentration of $\geq 1.0 \times 10^{-6} \mathrm{M}$ ) and can be used for 9 months without any considerable divergence in potentials. The proposed sensor exhibit relatively good selectivity and high sensitivity for tin(II) as other mono-, di-, and trivalent cations and can be used in a pH range of 2.0-8.5. The analytical usefulness of the proposed electrode has been evaluated by its application in the determination of stannous in artificially made samples.

\section{Introduction}

Tin is a natural element in the earth's crust. Tin metal is used to line cans for food, beverages, and aerosols. It can combine with chemicals like chlorine, sulfur, or oxygen to form inorganic tin compounds. These compounds are used in toothpaste, perfumes, soaps, food additives, and dyes. Tin can also combine with carbon to form organotin compounds which are used to make plastics, food packages, plastic pipes, pesticides, paints, and pest repellents. Inorganic tin compounds are used as pigments in the ceramic and textile industry. In addition, stannous chloride, $\mathrm{SnCl}_{2}$, is widely used in daily human life to conserve soft drinks, in food manufacturing, processing, and packaging, and in biocidal preparations. The available methods for determination of low concentrations of tin ion in solution include spectrophotometry $[1,2]$, atomic absorption spectrometry $[3,4]$, atomic emission spectrometry $[5,6]$, electrochemical methods $[7$, 8], and spectrofluorimetric methods [9]. These methods are either time consuming, involving multiple sample manipulation, or too expensive for the most analytical laboratories.
The potentiometric membrane sensors have shown to be very effective tools for the analysis of a wide variety of metal ions $[10,11]$. They are very simple, fast, inexpensive, and capable of providing reliable responses in a broad concentration range.

In the present study salicylaldehyde thiosemicarbazone was incorporated as the ionophore. It shows better potentiometric response as compared to the previously reported tin ion selective electrodes $[12,13]$ based on different ionophores.

\section{Experimental}

2.1. Reagents and Apparatus. Reagent-grade salicylaldehyde and thiosemicarbazide were obtained from Sigma-Aldrich (Delhi) used as purchased. DBP (dibutyl phthalate), DOP (dioctyl phthalate), $o$-NPOE (o-nitrophenyl octyl ether), and TBP (Tri-n-butyl phosphate) were purchased from Merck (Delhi). High-molecular-weight PVC powder, THF, and cation excluder NaTPB (sodium tetraphenyl borate) and metal salts were purchased from Fluka and Sigma-Aldrich. 


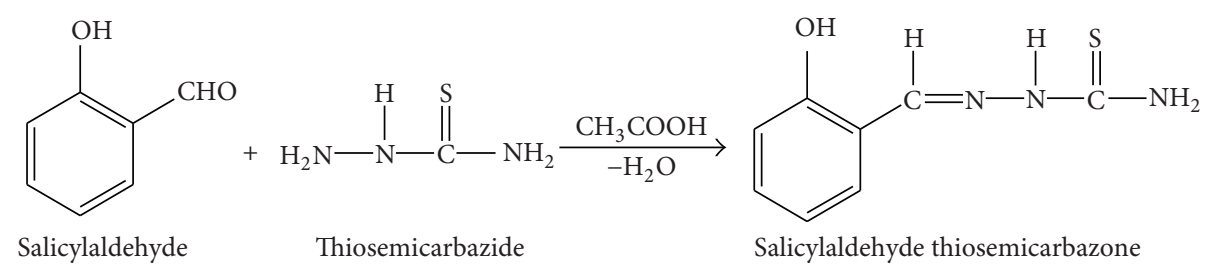

FIGURE 1: Syntheses of ionophore.

TABLE 1

\begin{tabular}{|c|c|c|c|c|}
\hline $\begin{array}{l}\text { External reference } \\
\text { electrode (SCE) }\end{array}$ & Aqueous sample & Ion-selective membrane & $\begin{array}{l}\text { Internal filling solution } \\
1.0 \times 10^{-2} \mathrm{M} \mathrm{Sn}\left(\mathrm{NO}_{3}\right)_{2}\end{array}$ & $\begin{array}{c}\text { Internal reference } \\
\text { solution (SCE) }\end{array}$ \\
\hline
\end{tabular}

All the reagents were of highest purity grade and used without further purification. Standard solutions were freshly prepared in deionized water.

2.2. Physical Measurement. The $\mathrm{C}, \mathrm{H}$, and $\mathrm{N}$ were analyzed on a carlo-Erba 1106 elemental analysis. Electron impact mass spectra were recorded on JEOL, JMS, DX-303 mass spectrophotometer; ${ }^{1} \mathrm{H}$ NMR spectra were recorded on a Hitachi FT-NMR, Model R-600 spectrophotometer using $\mathrm{CDCl}_{3}$ as solvent. IR spectra (KBr) were recorded on a Bruker FT-IR spectrophotometer (Delhi).

2.3. Synthesis of Ionophore. The hot ethanolic solutions $(20 \mathrm{~mL})$ of salicylaldehyde $(1.31 \mathrm{~mL} 0.01 \mathrm{mmol})$, thiosemicarbazide $(1.14 \mathrm{~g} 0.01 \mathrm{mmol})$ with few drops of acetic acid were mixed with constant stirring. This mixture was refluxed at $80 \pm 5^{\circ} \mathrm{C}$. On cooling a yellowish-coloured compound has separated out. It was filtered, washed several times with cold EtOH and dried in vacuum over $\mathrm{P}_{4} \mathrm{O}_{10}$ (see Figure 1).

2.4. Salicylaldehyde Thiosemicarbazone. Yield (75.0\%), M.P.: $184^{\circ}$ C. Anal. calc. for $(\%)=\mathrm{C}_{8} \mathrm{H}_{9} \mathrm{~N}_{3} \mathrm{OS}$ : C, 49.21; $\mathrm{H}, 4.65$; N, 21.52; O, 8.19. Found: (\%): C, 49.18; H, 4.64; N, 21.54; O, 8.11. Mass. $(\mathrm{m} / \mathrm{z}): 195.05(\mathrm{M}+)$ amu. FT-IR $(\mathrm{KBr}): v\left(\mathrm{NH}_{2}\right)$ $3173(\mathrm{~b}), v(\mathrm{NH}) 2987(\mathrm{~b}), v(\mathrm{C}=\mathrm{N}) 1538, v(\mathrm{C}=\mathrm{S}) 829$.

\section{Potential Measurements}

All the membrane electrode potential measurements were performed at constant temperature $\left(25 \pm 0.05^{\circ} \mathrm{C}\right)$ using digital $\mathrm{pH}$ meter and potentiometer (ELICO L1-10, India) in conjugation with saturated calomel electrodes as reference electrodes. The representation of electrochemical cell for the EMF measurements is shown in Table 1.

3.1. Electrode Preparation. The general procedure was used for the preparation of the PVC membrane. For the preparation of membrane contents' the fixed mixture of PVC: plasticizer:ionophore: excluder in 28:59:8.0:5.0 (w/w\%) was taken as fixed. The mixture was thoroughly dissolved in THF $(5 \mathrm{~mL})$. The resulting mixture was poured into a glass dish. The solvent evaporated slowly until a sticky and oily mixture was obtained. A $5 \mathrm{~mm}$ diameter Pyrex tube was dipped into this mixture for few seconds and then removed. To obtain a $0.3 \mathrm{~mm}$ thick nontransparent membrane, fix one end of the Pyrex tube. It was dried for $5 \mathrm{Hrs}$. Pyrex tube was then filled with $1.0 \times 10^{-2} \mathrm{M}$ $\mathrm{Sn}\left(\mathrm{NO}_{3}\right)_{2}$ as an internal filling solution. The electrode was kept as it is and conditioned for $24 \mathrm{hrs}$ by soaking it in $\mathrm{Sn}\left(\mathrm{NO}_{3}\right)_{2}$ solution. The blank membrane having only PVC as membrane ingredients was also prepared and studied, while membrane having PVC with plasticizer generates small potential with slope of $\sim 8.9 \mathrm{mV} /$ decade.

\section{Results and Discussion}

4.1. Effect of Membrane Composition and Response Characteristics. The response of different metal ions and rare earth ions as plotted as the negative log of concentration and the potential values obtained for different metal ions. Best response and slope were seen for the $\mathrm{Sn}^{2+}$ ion as compared to the other cations as shown Figure 2. The plot between the concentration and EMF in Figure 2 indicates that the best response was obtained for the $\mathrm{Sn}^{2+}$, whereas transition metal ion gave a poor response. The calibration curve slope was found to be $28.8 \pm 0.4 \mathrm{mV} /$ decade in the linear range of $1 \times$ $10^{-2}-1 \times 10^{-7} \mathrm{M} \mathrm{Sn}^{2+}$ concentration with the detection limit of $2.10 \times 10^{-8} \mathrm{M}$. Further result of changes in the membrane composition on the electrode response was studied. It is well known $[14,15]$ that sensitivity and selectivity obtained for a given ionophore is significantly affected by the membrane composition of an ion sensor membrane. The different membrane ingredients, such as amount of ionophore and nature of the plasticizer and additives, influence the potentiometric response behaviour of the sensor $[16,17]$. Best optimized studies membrane for $\mathrm{Sn}^{2+}$ selective electrode are reported in Table 2 sensor 2. The results given in the Table 2 show that the electrode worked well in plasticizer/PVC ratio of nearly 2, which ensures enough mobility of the membrane constituents. The best sensitivity and selectivity was recorded for TBP as plasticizer. Further the amount of ionophore also affected the Nernstian slope value. It has been observed (Table 2) that on increasing the concentration of the ionophore more than $2 \%(\mathrm{w} / \mathrm{w})$, the slope deteriorated and a narrow linear concentration range was achieved. Hence, a very small amount of ionophore is required for the study. The 
TABLE 2: Composition of PVC membrane of (STSC) and performance characteristics of $\mathrm{Sn}^{2+}$ selective sensors based on them.

\begin{tabular}{|c|c|c|c|c|c|c|}
\hline S. no. & PVC & Plasticizer & Ionophore & Excluder NaTPB & Slope (mv/decade) & Linear range \\
\hline 1 & 28 & 67 (TBP) & 0 & 5 & 8.9 & $1 \times 10^{-3}$ to $1 \times 10^{-6}$ \\
\hline 2 & 28 & 58 (ТВР) & 8 & 5 & 29.2 & $1 \times 10^{-2}$ to $1 \times 10^{-8}$ \\
\hline 3 & 28 & 57 (ТВP) & 5 & 5 & 35.7 & $1 \times 10^{-3}$ to $1 \times 10^{-7}$ \\
\hline 4 & 28 & 59 (ТВР) & 7 & 5 & 22.8 & $1 \times 10^{-2}$ to $1 \times 10^{-5}$ \\
\hline 6 & 28 & 57 (DOP) & 5 & 5 & 18.3 & $1 \times 10^{-3}$ to $1 \times 10^{-5}$ \\
\hline 7 & 28 & 58 (DOP) & 4 & 5 & 33.4 & $1 \times 10^{-2}$ to $1 \times 10^{-4}$ \\
\hline 8 & 28 & 59 (DOP) & 3 & 5 & 25.7 & $1 \times 10^{-2}$ to $1 \times 10^{-5}$ \\
\hline
\end{tabular}

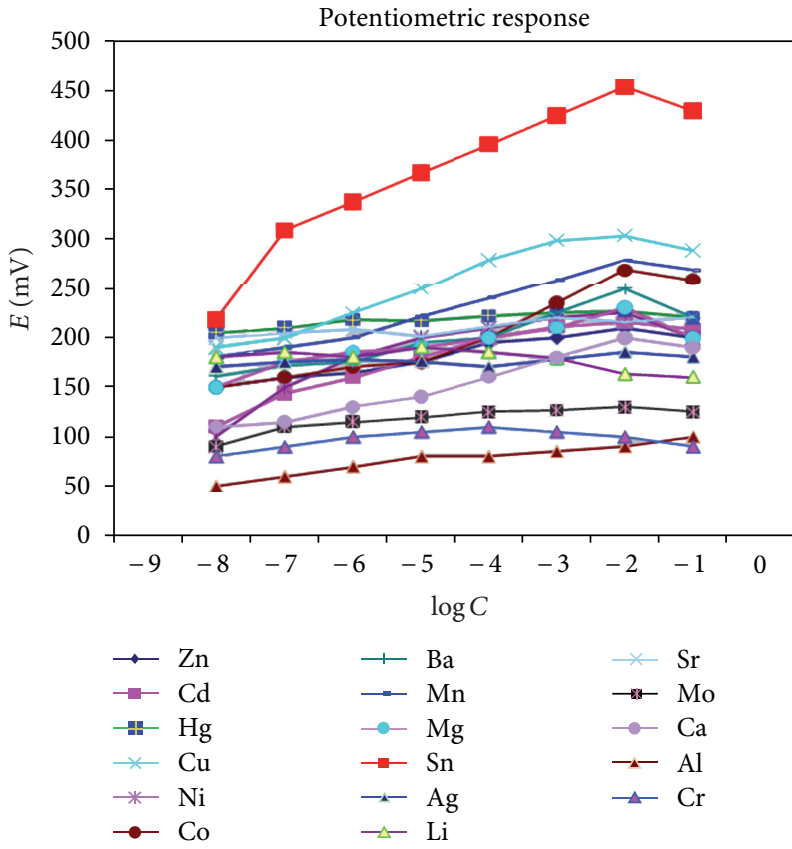

FIGURE 2: Potential response of various ion-selective electrodes based on STSC.

presence of lipophilic anion excluder in cation sensor based on neutral carrier not only reduces the ohmic resistance but also enhances the response behaviour and selectivity [14]. It also assists in the extraction capability of the carrier in the membrane electrodes study $[18,19]$. According to the results in Table 2, most optimum plasticizer used was TBP and the ionic additive $\mathrm{NaTPB}$, and the optimum ratio for further studies was PVC: TBP: ionophore: NaTPB as 28: 59: $8: 5$ (w/w\%).

4.2. $\mathrm{pH}$ and Nonaqueous Effect. The $\mathrm{pH}$ dependence of the electrode potential was tested over the range 0.5-14.0 for $\mathrm{Sn}^{2+}$ in concentration $1.0 \times 10^{-3}$ as shown in Figure 3 . The $\mathrm{pH}$ of the solutions was adjusted by the addition of dilute hydrochloric acid or sodium hydroxide. It is clear from Figure 3 that the useful $\mathrm{pH}$ range is $2.0-8.5$, as the potentials remain constant in this range. The sharp change in potentials at higher $\mathrm{pH}$ values may be due to the hydrolysis of $\mathrm{Sn}^{2+}$, while at lower $\mathrm{pH}$ values $\mathrm{H}^{+}$ions start contributing to the charge transport process of the membrane, thereby, causing interference.

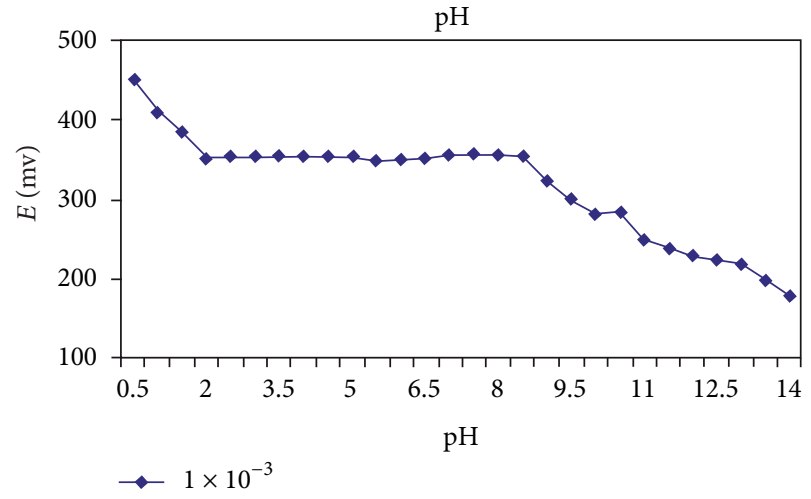

FIGURE 3: The effect of $\mathrm{pH}$ of test solution on the response of the $\mathrm{Sn}^{2+}$ ion-selective electrode.

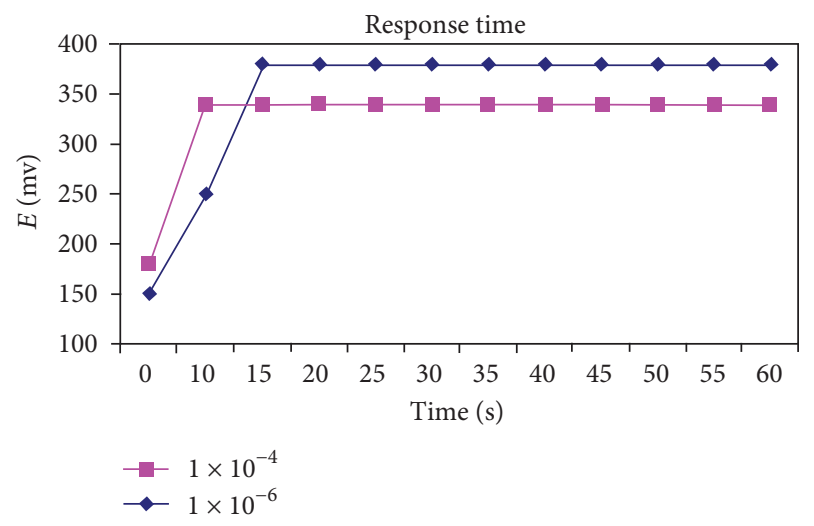

FIgURE 4: The effect of the time on potentiometric response of $\mathrm{Sn}^{2+}$ electrode.

4.3. Response and Lifetime. Response time is critically reviewed when it comes to analytical application of the sensor [20]. The static response time of the membrane sensor thus obtained was $<8 \mathrm{~s}$, for concentration $\geq 1.0 \times 10^{-4}$ and $<12 \mathrm{~s}$ for concentration of $\geq 10^{-6}$ (Figure 4 ). It should be noted that the equilibrium potential remains constant for more than $8 \mathrm{~min}$.

The lifetime of the membrane sensor was about 9 months, during which it could be used without any measurable divergence. The time of contact and concentration of the equilibrium solution was also optimized so that the stable sensor generated and reproducible potentials at relatively 
TABLE 3: Selectivity coefficient values $K_{\mathrm{A}, \mathrm{B}}^{\text {pot }}$ for $\mathrm{Sn}^{2+}$ selective sensor by fixed interference method.

\begin{tabular}{lcc}
\hline S. no. & Interfering ion (B) & Selectivity coefficients \\
\hline 1 & $\mathrm{~K}^{+}$ & $6.01 \times 10^{-4}$ \\
2 & $\mathrm{NH}_{4}^{+}$ & $4.03 \times 10^{-3}$ \\
3 & $\mathrm{Cd}^{2+}$ & $6.44 \times 10^{-4}$ \\
5 & $\mathrm{Cu}^{2+}$ & $4.03 \times 10^{-2}$ \\
6 & $\mathrm{Ni}^{2+}$ & $8.11 \times 10^{-2}$ \\
7 & $\mathrm{Zn}^{2+}$ & $5.12 \times 10^{-3}$ \\
8 & $\mathrm{Co}^{2+}$ & $2.01 \times 10^{-2}$ \\
9 & $\mathrm{Mn}^{2+}$ & $3.11 \times 10^{-3}$ \\
10 & $\mathrm{Ni}^{2+}$ & $3.11 \times 10^{-3}$ \\
11 & $\mathrm{Ag}^{+}$ & $2.51 \times 10^{-4}$ \\
12 & $\mathrm{Hg}^{2+}$ & $2.51 \times 10^{-3}$ \\
13 & $\mathrm{Ca}^{2+}$ & $1.06 \times 10^{-2}$ \\
14 & $\mathrm{Sr}^{2+}$ & $3.01 \times 10^{-2}$ \\
15 & $\mathrm{Cr}^{3+}$ & $1.01 \times 10^{-4}$ \\
16 & $\mathrm{Al}^{3+}$ & $6.01 \times 10^{-4}$ \\
17 & $\mathrm{Ti}^{+}$ & $2.1 \times 10^{-3}$ \\
18 & $\mathrm{Cs}^{+}$ & $2.06 \times 10^{-3}$ \\
19 & $\mathrm{Na}^{+}$ & $3.01 \times 10^{-3}$ \\
20 & $\mathrm{~Pb}^{2+}$ & $1.01 \times 10^{-3}$ \\
\hline
\end{tabular}

short response time obtained. It was found that an equilibrating solution of $1.0 \times 10^{-2} \mathrm{M}$ and contact time of $24 \mathrm{Hrs}$ was appropriate for smooth functioning of the electrode. Membranes were stored in $1.0 \times 10^{-2} \mathrm{M} \mathrm{Sn}\left(\mathrm{NO}_{3}\right)_{2}$ solution when not in used.

4.4. Potentiometric Selectivity. The selectivity is the most important characteristic, as it determines the extent of utility of a sensor in real sample measurement. The selectivity coefficient values were determined by fixed interference method (FIM) [20,21]. The selectivity coefficient values $K_{\mathrm{A}, \mathrm{B}}^{\text {pot }}$ indicate that the electrode is moderately selective to $\mathrm{Sn}^{2+}$ over a number of other cation (Table 3 ). The potential of a cell comprising an ion-selective electrode [22] and a reference electrode is measured with solutions of constant level of interference, $a_{\mathrm{B}}$, and varying activity of the primary ion, $a_{\mathrm{A}}$. The potential values obtained are plotted against the activity of the primary ion. The intersection of the extrapolation of the linear portions of this curve will give the value of $a_{\mathrm{A}}$ which is to be used to calculate $K_{\mathrm{A}, \mathrm{B}}^{\mathrm{pot}}$ from the equation:

$$
K_{\mathrm{A}, \mathrm{B}}^{\mathrm{pot}}=\left(\frac{a_{\mathrm{A}}}{a_{\mathrm{B}}}\right)^{Z_{\mathrm{A}} / Z_{\mathrm{B}}},
$$

where both $Z_{\mathrm{A}}$ and $Z_{\mathrm{B}}$ have the same signs, positive or negative. Value of selectivity coefficient equal to 1.0 indicates that the sensor responds equally to primary as well as interfering ions. However, values smaller than 1.0 indicate that membrane sensor is responding more to primary ion than to interfering ions and in such a cases the sensor is said to be selective to primary ion over interfering ion. Further, the smaller the selectivity coefficient is, the higher the selectivity
TABLE 4: Determination of $\mathrm{Sn}^{2+}$ concentrations in different artificially made samples.

\begin{tabular}{|c|c|c|}
\hline $\begin{array}{l}\text { Artificially made } \\
\text { samples }\end{array}$ & $\begin{array}{c}\mathrm{Sn}^{2+} \text { sensor } \\
\text { (Found) }\end{array}$ & $\begin{array}{c}\text { By Titration } \\
\text { method }\end{array}$ \\
\hline $\begin{array}{l}\mathrm{S}-1(25 \mathrm{ppm}) \\
4.8 \mathrm{mg}\end{array}$ & $4.7 \mathrm{mg} \pm 0.05$ & $4.6 \mathrm{mg} \pm 0.08$ \\
\hline $\begin{array}{l}\text { S-2 (50 ppm), } \\
9.6 \mathrm{mg}\end{array}$ & $9.5 \mathrm{mg} \pm 0.04$ & $9.7 \mathrm{mg} \pm 0.05$ \\
\hline $\begin{array}{l}\text { S-3 (75 ppm), } \\
14.4 \mathrm{mg}\end{array}$ & $14.8 \mathrm{mg} \pm 0.01$ & $14.3 \mathrm{mg} \pm 0.07$ \\
\hline $\begin{array}{l}\mathrm{S}-4(100 \mathrm{ppm}) \\
19.2 \mathrm{mg}\end{array}$ & $19.0 \mathrm{mg} \pm 0.09$ & $19.1 \mathrm{mg} \pm 0.02$ \\
\hline $\begin{array}{l}\mathrm{S}-5(125 \mathrm{ppm}) \\
24.0 \mathrm{mg}\end{array}$ & $24.1 \mathrm{mg} \pm 0.01$ & $24.2 \mathrm{mg} \pm 0.04$ \\
\hline $\begin{array}{l}\mathrm{S}-6(250 \mathrm{ppm}) \\
48.0 \mathrm{mg}\end{array}$ & $48.1 \mathrm{mg} \pm 0.08$ & $48.5 \mathrm{mg} \pm 0.06$ \\
\hline $\begin{array}{l}\text { S-7 (500 ppm), } \\
96.03 \mathrm{mg}\end{array}$ & $96.2 \mathrm{mg} \pm 0.04$ & $96.1 \mathrm{mg} \pm 0.08$ \\
\hline $\begin{array}{l}\text { S-8 (1000 ppm), } \\
192.06 \mathrm{mg}\end{array}$ & $192.1 \mathrm{mg} \pm 0.05$ & $192.1 \mathrm{mg} \pm 0.04$ \\
\hline
\end{tabular}

order is. A perusal of Table 4 shows that selectivity coefficient values for the present sensor are much smaller than 1.0 over a number of studied mono-, di-, and trivalent cations. Hence, the sensor is sufficiently selective over these ions and can therefore be used to estimate tin in the presence of these ions by direct potentiometry.

4.5. Analytical Applications. The analytical application of proposed work (sensor no. 2) is evaluated by estimation of $\mathrm{Sn}^{2+}$ concentrations in different artificially made samples with simple starch-iodine-based titration. To prepare the sample of different concentration's samples $4.8 \mathrm{mg}$ (25 ppm), $9.6 \mathrm{mg}$ (50 ppm) $14.4 \mathrm{mg}(75 \mathrm{ppm}), 19.2 \mathrm{mg}$ (100 ppm), $24 \mathrm{mg}$ (125 ppm), $48 \mathrm{mg}$ (250 ppm), $96.03 \mathrm{mg}$ (500 ppm), and $192.06 \mathrm{mg}(1000 \mathrm{ppm})$ of $\mathrm{SnCl}_{2} \cdot 2 \mathrm{H}_{2} \mathrm{O}$ accurately weighed, add to a $100 \mathrm{~mL}$ volumetric flask, dissolve in $25 \mathrm{~mL}$ of hydrochloric acid, dilute to volume with water, and mix well. Transfer $50 \mathrm{~mL}$ of this solution to a $500 \mathrm{~mL}$ conical flask, and add $5 \mathrm{~g}$ of potassium sodium tartrate, and then a cold saturated solution of sodium bicarbonate until the solution is alkaline to litmus paper. Titrate at once with $0.1 \mathrm{~N}$ iodine using starch TS as the indicator. The obtained results were comparatively compiled with sensor no. 2 in Table 4 . Each $\mathrm{mL}$ of $0.1 \mathrm{~N}$ iodine consumed is equivalent to $11.28 \mathrm{mg}$ of $\mathrm{SnCl}_{2} \cdot 2 \mathrm{H}_{2} \mathrm{O}$.

\section{Conclusions}

In this work, the first $\mathrm{Sn}$ (II) electrochemical sensor was introduced based on of salicylaldehyde thiosemicarbazone (STSC) as a sensing material. The proposed electrochemical sensor with a membrane composition containing $28 \%$ poly(vinyl chloride) (PVC), 59\% tri-n-butyl phosphate (TBP) as solvent mediator, $5 \%$ sodium tetraphenylborate (NaTPB) as cation excluder, and 8\% STSC worked as an ionophore. The 
electrochemical sensor exhibits a nice Nernstian response of $28.8 \pm 0.4 \mathrm{mV}$ per decade of tin activity and a wide dynamic working range $1.0 \times 10^{-2}-1.1 \times 10^{-7} \mathrm{M}$. The detection limit of the sensor is $2.10 \times 10^{-8} \mathrm{M}$ and can be used in the $\mathrm{pH}$ range of 2.0-8.5. The electrochemical sensor has fast response time and relatively long lifetime (more than 9 months).

\section{Acknowledgment}

The financial support provided by the Defense Research and Development Organization (DRDO), New Delhi, India is greatly acknowledged.

\section{References}

[1] A. C. S. Costa, L. S. G. Teixeira, and S. L. C. Ferreira, "Spectrophotometric determination of tin in copper-based alloys using pyrocatechol violet," Talanta, vol. 42, no. 12, pp. 1973-1978, 1995.

[2] X. Huang, W. Zhang, S. Han, and X. Wang, "Determination of tin in canned foods by UV/visible spectrophotometric technique using mixed surfactants," Talanta, vol. 44, no. 5, pp. 817-822, 1997.

[3] H. O. Haug and L. Yiping, "Automated determination of tin by hydride generation using in situ trapping on stable coatings in graphite furnace atomic absorption spectrometry," Spectrochimica Acta B, vol. 50, no. 11, pp. 1311-1324, 1995.

[4] N. Carrión, A. M. Itriago, M. A. Alvarez, and E. Eljuri, "Simultaneous determination of lead, nickel, tin and copper in aluminium-base alloys using slurry sampling by electrical discharge and multielement ETAAS," Talanta, vol. 61, no. 5, pp. 621-632, 2003.

[5] L. Perring and M. Basic Dvorzak, "Determination of total tin in canned food using inductively coupled plasma atomic emission spectroscopy," Analytical and Bioanalytical Chemistry, vol. 374, no. 2, pp. 234-243, 2002.

[6] A. S. Ribeiro, A. L. Moretto, M. A. Z. Arruda, and S. Cadore, "Analysis of powdered coffee and milk by ICP OES after sample treatment with tetramethylammonium hydroxide," Mikrochimica Acta, vol. 141, no. 3-4, pp. 149-155, 2003.

[7] Y. Li, H. Long, and F. Zhou, "Determination of trace tin by catalytic adsorptive cathodic stripping voltammetry," Analytica Chimica Acta, vol. 554, no. 1-2, pp. 86-91, 2005.

[8] Y. H. Li, H. Q. Xie, F. Q. Zhou, and H. S. Guo, "Determination of trace tin by anodic stripping voltammetry at a carbon paste electrode," Electroanalysis, vol. 18, no. 10, pp. 976-980, 2006.

[9] J. L. Manzoori, M. Amjadi, and D. Abolhasani, "Spectrofluorimetric determination of tin in canned foods," Journal of Hazardous Materials, vol. 137, no. 3, pp. 1631-1635, 2006.

[10] F. Faridbod, M. R. Ganjali, R. Dinarvand, and P. Norouzi, "The fabrication of potentiometric membrane sensors and their applications," African Journal of Biotechnology, vol. 6, no. 25, pp. 2960-2987, 2007.

[11] M. Arvand, A. M. Moghimi, A. Afshari, and N. Mahmoodi, "Potentiometric membrane sensor based on 6-(4-nitrophenyl)2,4-diphenyl-3,5-diaza-bicyclo[3.1.0] hex-2-ene for detection of Sn(II) in real samples," Analytica Chimica Acta, vol. 579, no. 1, pp. 102-108, 2006.
[12] J. Hamdan and A. Adullah, "Sn (II) selective 2-amino-1,4naphthoquinone derived poly(vinyl chloride) membrane sensors," International Journal of Electrochemical Science, vol. 5, pp. 215-231, 2010.

[13] S. Chandra, A. Rawat, and A. Sarkar, "Thiocyanate-selective PVC membrane electrode based on copper and nickel complexes of para-tolualdehydesemicarbazone as carrier," Analytical Letters, vol. 41, no. 17, pp. 3058-3073, 2008.

[14] S. Chandra and S. Dev Raj, "Development of $\operatorname{Pr}(\mathrm{III})$ selective electrode using 1,6,7,12-Tetramine-2,5,8,11-tetraoxo1(12),6(7)-di(biphenyl)-dodecane (TATODBDD) as a neutral carrier," Chinese Journal of Chemistry, vol. 28, no. 5, pp. 833-838, 2010.

[15] M. R. Ganjali, P. Norouzi, M. Adib, and A. Ahmadalinezhad, "A novel holmium(III) membrane sensor based on N-(1-thien2-ylmethylene)-1,3-benzothiazol-2-amine," Analytical Letters, vol. 39, no. 6, pp. 1075-1086, 2006.

[16] H. A. Zamani, M. R. Ganjali, P. Norouzi, and S. Meghdadi, "Application of novel praseodymium (III) PVC-membrane electrode for determination of $\operatorname{Pr}(\mathrm{III})$ ions in soil and sediment samples," Analytical Letters, vol. 41, no. 5, pp. 902-916, 2008.

[17] J. L. Lin and H. Y. Hsu, "Study of sodium ion selective electrodes and differential structures with anodized indium tin oxide," Sensors, vol. 10, no. 3, pp. 1798-1809, 2010.

[18] E. Bakker, P. Bühlmann, and E. Pretsch, "Polymer membrane ion-selective electrodes-what are the limits?" Electroanalysis, vol. 11, no. 13, pp. 915-933, 1999.

[19] C. Macca, "Response time of ion-selective electrodes: current usage versus IUPAC recommendations," Analytica Chimica Acta, vol. 512, no. 2, pp. 183-190, 2004.

[20] F. J. S. De Viteri and D. Diamond, "Determination and application of ion-selective electrode model parameters using flow injection and simplex optimization," The Analyst, vol. 119, no. 5, pp. 749-758, 1994.

[21] E. Bakker, E. Pretsch, and P. Bühlmann, "Selectivity of potentiometric ion sensors," Analytical Chemistry, vol. 72, no. 6, pp. 1127-1133, 2000.

[22] R. N. Goyal, V. K. Gupta, and S. Chatterjee, "Electrochemical investigations of corticosteroid isomers-testosterone and epitestosterone and their simultaneous determination in human urine," Analytica Chimica Acta, vol. 657, no. 2, pp. 147-153, 2010. 

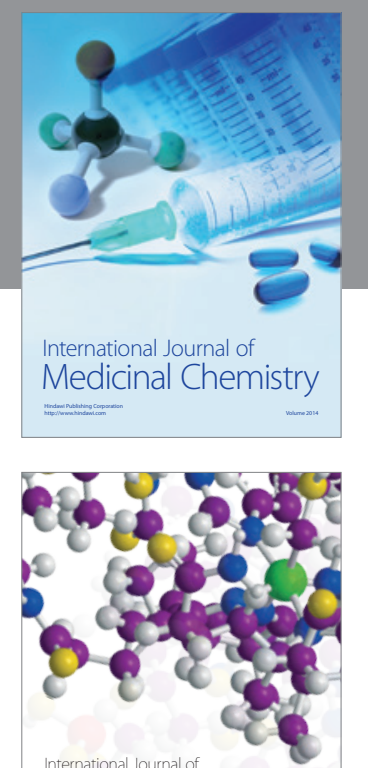

\section{Carbohydrate} Chemistry

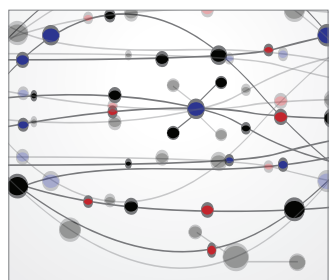

The Scientific World Journal
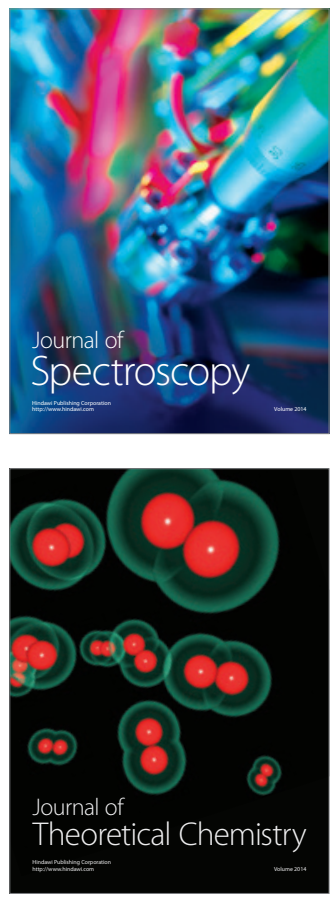
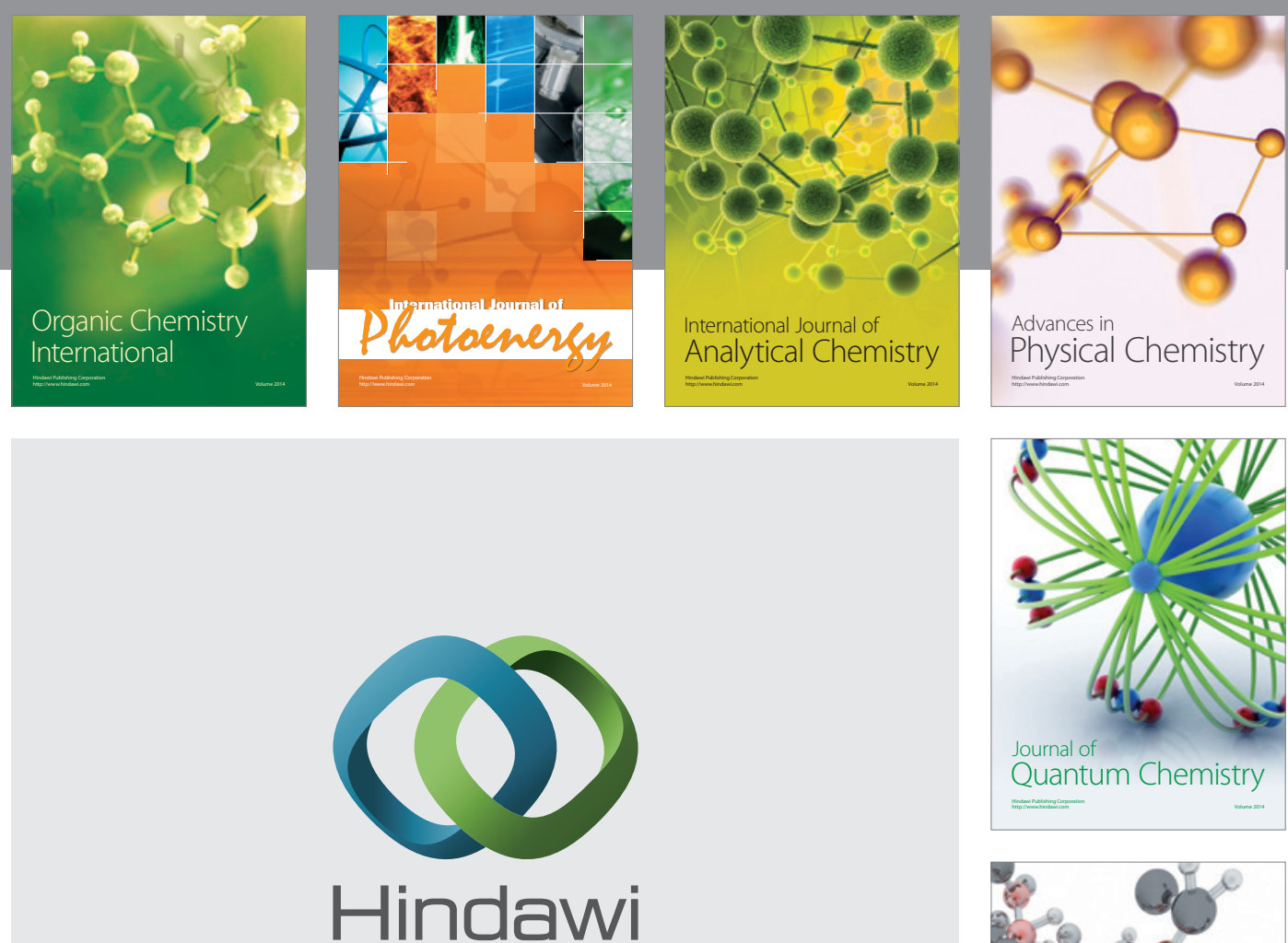

Submit your manuscripts at

http://www.hindawi.com

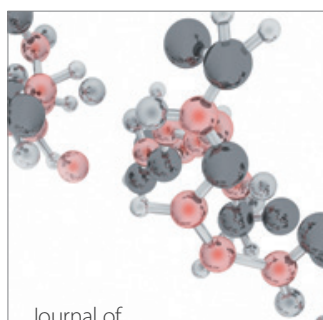

Analytical Methods

in Chemistry

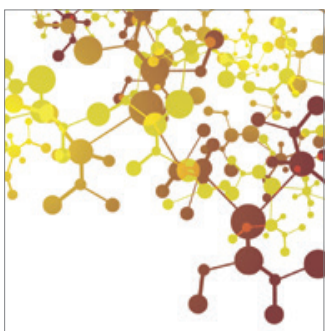

Journal of

Applied Chemistry

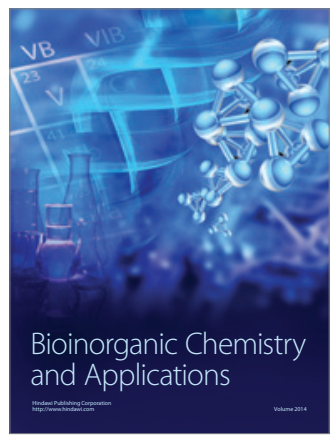

Inorganic Chemistry
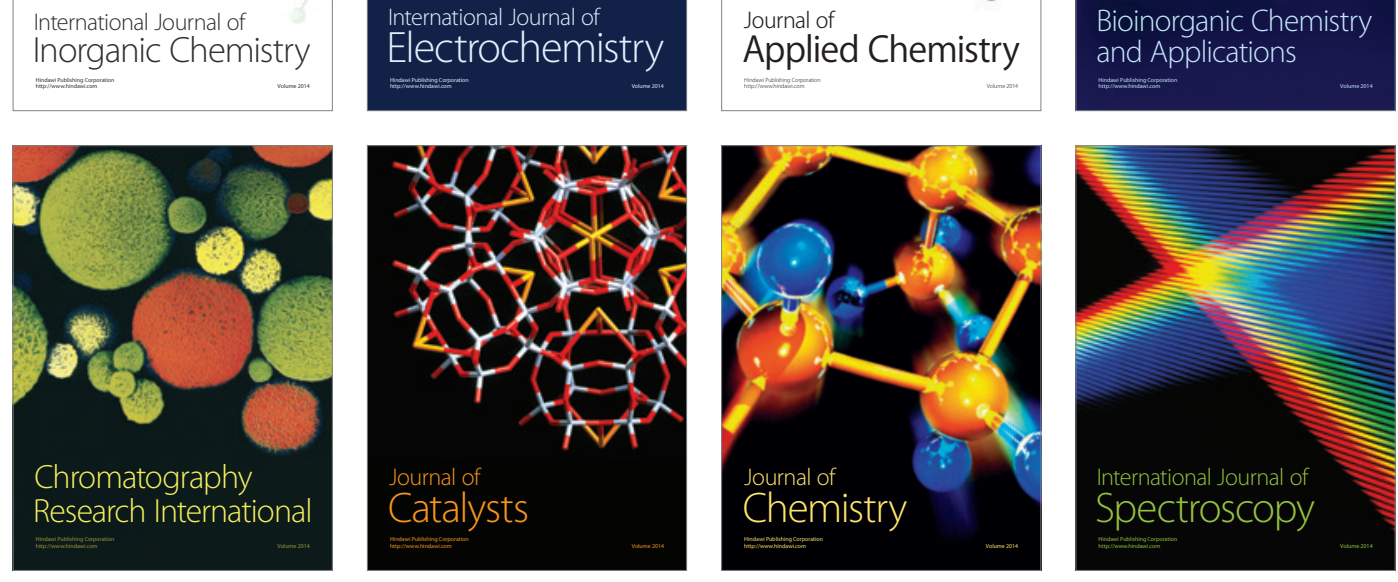